\title{
The Music Instruction of the Special Program in the Arts: Grade 9 students of DepEd Region X, Philippines
}

\author{
Gerry Pol P. Cainoy., Renato L. Base, Ph.D., Loida D. Cainoy \\ gerrypolphd@gmail.com, renato.base@ustp.edu.ph, \\ loidacainoy1@gmail.com \\ Mindanao University of Science and Technology \\ Cagayan de Oro City, 9000 Philippines \\ Sugbongcogon National High School, \\ Sugbongcogon, Misamis Oriental, 9009 Philippines
}

\begin{abstract}
The study utilized descriptive design which endeavors to examine and evaluate the music instruction in the Special Program in the Arts in selected SPA schools in Region X. The participants of study were all the Grade 9 SPA Music students in the selected SPA schools in Region X, during the school year 2019-2020. The researcher used two (2) sets of assessment tools to evaluate knowledge on music theory and singing ability of students. The first set of tool is a written examination-and the second set is a Scoring Rubrics to rate (Dep Ed Order No 73, s. 2012) the singing ability of the students. Three music experts evaluated the students' singing ability using rubrics. The students were rated according to given criteria such as melody, rhythm, timbre, and dynamics. Students were also rated for musicianship and stage presence. Most of the student-respondents mastered the Intensity level of sound/music and they also Mastered the minor/major scale pattern. A clear evident that after seventeen years of implementation of SPA Music Program, teachers and administrator enhance their teaching-learning styles to suit the needs of the students.

The students' performance in music theory is approaching proficient indicates that the SPA Music Program is well-organized and still progressing. This dissertation sheds light on the Department of Education to strengthen its instructions, guidelines, and policies on the Special Program in the Arts.
\end{abstract}

Keywords: Education, music instruction, Special Program in the Arts(SPA), descriptive design, Philippines, Asia

Abstract

\section{Introduction}

In August 11, 2001, the Philippine Congress passed Republic Act No. 9155, (Congress of the Philippines, 2001) wherein a framework of governance for basic education was instituted. According to the Implementing Rules and Regulations (IRR) of the said law, one of its purpose and objective was

[t]o establish schools and learning centers, and other school facilities where school children are able to learn a range of core competencies prescribed for elementary and high school programs or where the out-ofschool youth and adult learners are provided alternative learning programs and receive accreditation for at least the equivalent of an elementary or a 
high school education. (Department of Education, 2003a) [Underscoring added]

In response to this, curricula were then designed that follows the spiral approach across subjects. These curricula would build on same concepts that were then developed in increasing complexity and sophistication. Thus, students are expected at the end of Grade 10 to demonstrate communicative competence; think intelligently, critically and creatively in life situation, make informed and value-based decisions; perform their civic duties; use resources sustainably; and participate actively in artistic and cultural activities and in the promotion of wellness and lifelong fitness (Department of Education, 2003a).

One particular curriculum that was design in response to the aforementioned objective is the Special Program for Arts (SPA) particularly the Music Program (Department of Education, 2003a). The Music Program focuses on the learner as the recipient of knowledge, skills, and values necessary for artistic expression and cultural literacy (Department of Education, 2003b). Subsequently, within the same year the IRR was promulgated, activities were then conducted to facilitate the implementation of SPA (Department of Education, 2003c; 2003d).

Presently, after seventeen years of implementation of SPA Music Program, the Department of Education Region-X have yet to conduct an assessment review of its SPA Music Program though it had conducted a Rodalla Training of Trainors (NTOT) Mindanao Cluster (Memoranda 2017, 2017) as well as conducted Festival of Talents (Department of Education Region-X Northern Mindanao, 2018). Nonetheless, it has yet to conduct an assessment of the performance of the Music Program based on the prescribed standards as per Department Order 31 s. 2012 (Department of Education, 2012).

Because of this, glaring gap appeared more noticeable. This gap became more pronounced since currently there is dearth of literature, and as far this researcher is concerned, there is so far no year-end review or assessment/evaluation studies relative to how the curriculum of SPA Music Program in DepEd Region-X is getting along in relation to our present knowledge economy; and, also in relation to the advancement of technology and pedagogical techniques in music. As a result of this, it is not yet clear at this time whether SPA curriculum on Music Program have meet its objective and purpose and whether its curriculum is still responsive to the demands of the present times. Therefore, this scarcity or even nonexistent studies and assessments being conducted on SPA Music Program particularly in DepEd Region- 
$\mathrm{X}$ served as an impetus to conduct this study though set in a context which could be considered limited given the fact that this study only attempted to assessed selected SPA Music Program in Region-X.

\section{Statement of the Problem}

In view of the above discussion, the main objective of the study was to come up with evidencebased recommendations that could address the present challenges facing the SPA Music Program in Region-X. Such recommendations would then be presented to the Curriculum Learning Management Division (CLMD) at DepEd Region-X to be utilized for appropriate policy formulation relative to SPA Music Program in the region.

To come up with empirical evidence that could be the basis in this study's recommendations, the study therefore attempted to shed light to the following considerations, namely, profile of teachers, extent of SPA guidelines implementation, performance of students in terms of content-standards and performance-standards, difference in student performance (if any), and whether teachers educational qualification and teaching experience in music correlates with student performance. To provide understanding on these considerations were the basis wherein evidence-based recommendations could be possibly crafted.

With this in mind, the study attempted to answer the following queries:

1. What is the profile of the music program teachers in the aforesaid five schools in Region-X, in terms of:

1. Gender

2. Age

3. Educational Attainment

4. Field of Specialization

5. Teaching Experience in Music

6. Teaching Skills in Music

2. To what extent the five SPA schools have implemented the guidelines in terms of:

1. Student selection

2. Qualification of music teacher

3. Curriculum 
4. Physical facilities/equipment

3. What is the performance of music students in terms of content-standards, as made evident in music theory?

4. What is the performance of music students in terms of performance-standards, as made evident in their music performance?

5. Is there a significant difference in student performance in terms of content-standards and performance-standards?

6. Is student content-standards associated with teachers:

1. Educational qualification

2. Teaching experience in music (in number of years)

7. Is student-performance standards associated with teachers:

1. Educational attainment

2. Field of specialization

3. Teaching experience in music (in number of years)

\section{Conceptual and Theoretical Framework}

In view of the concepts mentioned above, the phenomena being studied is herein represented diagrammatically. This graphical representation serves to show the concepts or variables that are out there in SPA Music Program, and the presumed dynamics that existed in them.

\section{REVIEW OF RELATED LITERATURE AND STUDIES}

\section{A Music Learning Theory for Newborn and Children}

This theory is conceptualized by Edwin E. Gordon (2003). According to him, music instruction is a formal instruction. This means that the teacher is required to specifically plan their music lessons in a given period of time. Teachers' teaching style must specifically ignite students' response. He explained that home is the most important school for children. It is because parents are capable of teaching music to their children. Gordon believed that every human person has a gift of musicality.

In addition, Gordon illustrates that children mostly learn song/music through media. However, parents must sing with them so that learning process will be completed. "To expect the children to sing 
songs, with or without lyrics, without first able to sing tonal patters and to chant rhythm patters, it like expecting them to recite poems before they can speak words, phrases, and sentences." Formal instruction means includes teaching groups of children to sing. Repetition is required so that children may fully learned.

Furthermore, Gordon introduced another essential principle in music instruction, he called it music aptitudes. Music aptitude measures children potential to learn music. In other words, this is the "inner possibilities." The fundamental objective of knowing one's aptitude is that music teachers can adjust his/her teaching styles that suits students' needs. Considering that every person is a unique individual, teachers must adjust. For instance, one student learns fast if the instruction is done in private/individual coaching, while others learned in groups. Knowing students' aptitude is done through controlled and systematic observation.

These are the basic characteristics of music aptitude. One, every child has music aptitude. Two, child's music is innate. However, the environment out can greatly affect one's musical aptitude. Lastly, if the child is exposed to rich environment, child's level of aptitude increased.

\section{A Generative Theory of Tonal Music}

Fred Lerdahl and Ray Jackendoff (1983) presented another musical instruction theories. First, they claimed that generative linguistic theory is attempt to characterize what a human being knows how to speak the language. Second, the basic concepts of musical dimensions includes the following: rhythmic, pitch organization, dynamic and timbral differentiation, and motivic-thematic processes. These dimensions played a pivotal role in the development of hierarchical structure of a musical piece.

\section{Theory of Learning by David Ausubel}

Ausubel's focus was on meaningful learning rather than memorisation learning. Meaning occurs when new information is taken into a person's existing cognitive structure and is related to the previously learned content forming new connections between this new information and the existing information. To him all learning takes place the same way by being compared and contrasted with prior knowledge that exists in a person's cognitive structure. If a person has relevant content in his or her existing cognitive structure to which the new information can be related, then the learning can be meaningful. 
The followings are the major international music education methods. First is the Dalcroze method. This method was developed in the early 20th century by Swiss musician and educator Émile Jaques-

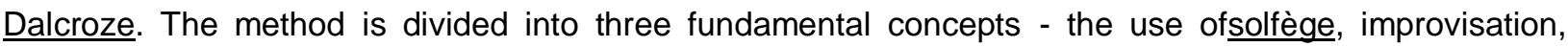
and eurhythmics. Sometimes referred to as "rhythmic gymnastics", eurhythmics teaches concepts of rhythm, structure, and musical expression using movement. It allows the student to gain physical awareness and experience of music through training that takes place through all of the senses, particularly kinesthetic. According to the Dalcroze method, music is the fundamental language of the human brain. That is why it is deeply connected to what human beings.

Another music education method was introduced by Zoltán Kodály (1882-1967). He was a prominent Hungarian music educator and composer who stressed the benefits of physical instruction and response to music. The fundamental objective of Kodály's method was to instill a lifelong love of music to his students. Kodály introduced the use of solfègehand signs, musical shorthand notation, and rhythm solmization.

\section{K to 12 Curriculum Guide: MUSIC}

Music permeates the daily lives of indigenous culture groups. it is commonly used in connection with life-cycle events such as birth, courtship, marriage and death. Occupational activities such as planting, harvesting, hunting and fishing and functions such as peace pacts and victory celebrations are occasions for music making. Lullabies are sung to put babies to sleep, instruments are played to drive away evil spirits and songs and chants accompany the playing of children. In these communities, singing of songs and playing of instruments are naturally learned through participation. Formal ways of learning are however practiced among many culture groups.

According to William Bennett, the arts are an essential element of education, just like reading, writing, and arithmetic, music, dance, painting, and theater are all keys that unlock profound human understanding and accomplishment. Thus, music education is a field of study associated with the teaching and learning of music. It hints on all domains of learning, including the psychomotor domain, the cognitive domain, and significantly touches the affective domain, including music appreciation and sensitivity. The incorporation of music training from preschool to postsecondary education is common in 
most nations because involvement in music is considered a fundamental component of

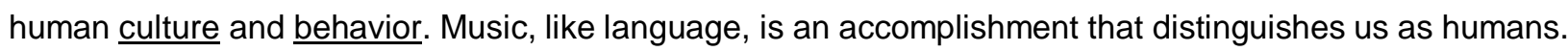

\section{Republic Act 10533}

Republic Act 10533 gives every Filipino student an opportunity to received quality education that is globally competitive based on a pedagogically sound curriculum that is internationally accepted and adopted. DepEd memorandum no. 139, s. 2011 promotes Original Pilipino Music Development Program. It aims to preserve and promote Filipino culture through composition and performance of Original Pilipino Music. This program is offered to $4^{\text {th }}$ year students enrolled in Special program in Arts (SPA). This course shall take the place of Music component of MAPEH. Thus, the primary purpose of this law is to create a functional basic education system that enhance productive, responsible, and values oriented Filipino citizen.

\section{RESEARCH METHODOLOGY and DATA}

This study was conducted in the five pioneering SPA schools in Region X. Participating schools will were: Bukidnon National High School (BNHS), in Malaybalay City, Gingoog Comprehensive National High School, in Gingoog City, Iligan City East High School ICEHS), in Santa Filomena, Iligan City, Lapasan National High School, Cagayan de Oro City, and Misamis Occidental National High School (MONHS), in Oroquita City. There are 16 SPA schools in Region X. 


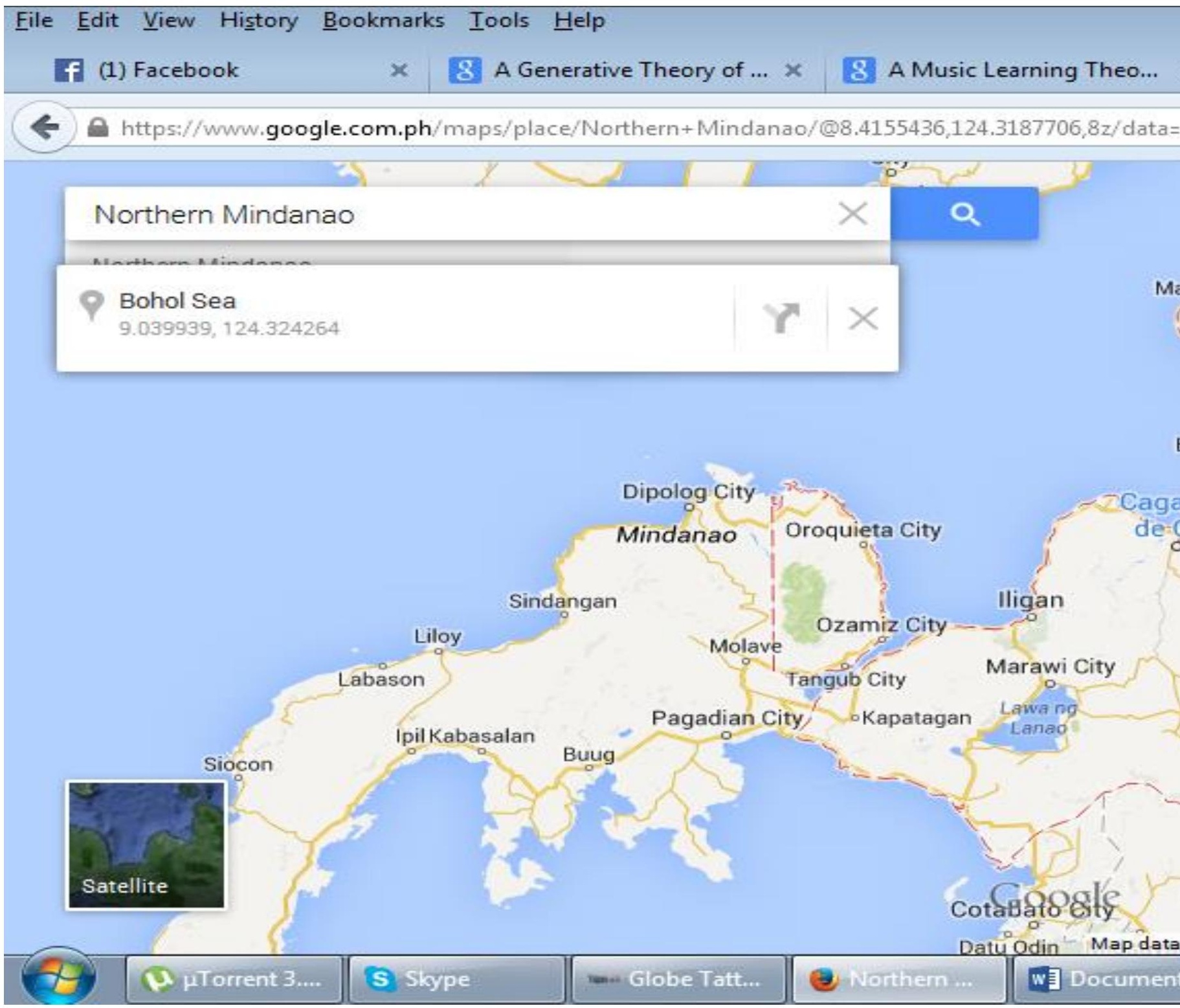

Northern Mindanao is a region of the Philippines, designated as Region $\mathrm{X}$. There are five

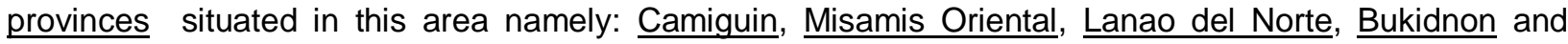
Misamis Occidental and cities that are classified as highly urbanized, all occupying the north-central part of Mindanao island, and the island-province of Camiguin. Cagayan de Oro City is called the "gate way" to Mindanao because it is the regional center and entrance to other regions in Mindanao. By virtue of Executive Order No. 36, Lanao del Norte was transferred to Northern Mindanao from Region XII. There are 12 divisions in Region 10. 
The researcher used two (2) sets of assessment tools to evaluate knowledge on music theory and singing ability of students.

The first set of tool was a 50 item written examination. Students were asked to answer the questions. No time limit was given. This was prepared by the researcher.

The second set was a Scoring Rubrics to rate the singing ability of the students. A music expert evaluated the students using rubrics. The students were rated according to given criteria such as melody, rhythm, timbre, and dynamics. The maximum and minimum rating for each criteria were 5 points and 1 point respectively. Students were rated for musicianship and stage presence. (Dep Ed Order No 73, s. 2012)

\section{Scoring Procedure}

For the written examination, one point is given for every correct answer. To rate the knowledge of music theory, the following values shall be observed.

$\begin{array}{llll}45 & - & 50 & \text { - Excellent } \\ 34 & - & 44 & \text { - Very Satisfactory } \\ 21 & - & 33 & \text { - Satisfactory } \\ 11 & - & 22 & \text { - Fair } \\ 0 & - & 12 & \text { - Needs Improvement }\end{array}$

To rate the singing ability of the students the following values shall be observed

$\begin{array}{llll}27 & - & 30 & \text { - Excellent } \\ 20 & - & 26 & \text { - Very Satisfactory } \\ 13 & - & 19 & \text { - Satisfactory } \\ 6 & - & 12 & \text { - Fair } \\ 0 & - & 6 & \text { - Needs Improvement }\end{array}$

\section{Data Gathering Procedures}

The study was conducted during the school year 2019 to 2020. The researcher secured permission from the Regional Director to conduct this study. After the approval, the researcher went to the Schools Division Superintendent asking his/her permission to conduct the study. 


\section{RESULTS AND DISCUSSION}

This chapter presents the data gathered, their analysis, and their interpretation. The data are presented according to the problem of the study.

According Aristotle "Music has a power of forming the character and should therefore be introduced into the education of the young"(http://pimperne.dorset.sch.uk/wp-content/uploads/2017/09/Music.pdf) Problem 1. What is the Profile of the Music program teachers in the aforesaid five schools in Region-X, in terms of: age, gender, educational qualification, field of specialization, teaching experience in music and skills.

Table 1 shows the teacher respondent's demographic profile. Teachers is the most important element in the teaching-learning process. Teacher sets the authority inside the classroom; they are the rule model, maintains high morale and sets the tone of the classroom.

Table 1

Distribution of Teacher-Respondents According to Gender and Age

\begin{tabular}{|c|c|c|}
\hline Characteristics & Frequency & Percentage \\
\hline \multicolumn{3}{|l|}{ Gender: } \\
\hline Male & 10 & 40.0 \\
\hline Female & 15 & 60.0 \\
\hline Total & 25 & 100.0 \\
\hline
\end{tabular}

\begin{tabular}{|c|c|c|}
\hline Age: & & \\
\hline $23-29$ & 8 & 32.0 \\
\hline $30-39$ & 5 & 20.0 \\
\hline $40-49$ & 6 & 24.0 \\
\hline 50-59 & 6 & 24.0 \\
\hline Total & 25 & 100.0 \\
\hline
\end{tabular}

Table 1 shows that majority, 15 or $60 \%$ of the teacher-respondents where female and 10 or $40 \%$ of them are male. 
Among the 25 teacher-respondents, 8 of them are 23 to 29 years old that represents $32 \%$, followed by the teacher-respondents who belong to the age range 30 to 39,40 to 49 and 50 to 59 years old representing $20 \%, 24 \%$ and another $24 \%$, respectively.

This finding reveals that most of the respondents belong to the age range of 23 to 29 years old, they were young and a newly hired professional teachers. Now adays, we are in $21^{\text {st }}$ century, thus, advance technology and a new curriculum was implemented. The newly hired teachers were very active and more advanced in terms of technology and was exposed to a different style of leaning. Based on the interview, one of them even mentioned that she was willing to attend all the seminars to acquire new knowledge and improved her teaching skills.

Table 2 presents the frequency and percentage distribution of the teacher-respondents according to their educational qualification. Thus, educational background is very crucial in the acquisition and development of skills and competencies to the teachers.

Table 2

Educational Qualification of Teachers

\begin{tabular}{|l|c|c|}
\hline \multicolumn{1}{|c|}{ Educational Qualification } & Frequency & Percentage \\
\hline Undergraduate & 2 & 8.0 \\
\hline AB-BSE & 13 & 52.0 \\
\hline BEED-BSED & 1 & 4.0 \\
\hline ABSE-PHEM & 1 & 4.0 \\
\hline Bachelor of PE & 7 & 28.0 \\
\hline Bachelor of Music & 1 & 4.0 \\
\hline BSBA Total & $\mathbf{2 5}$ & $\mathbf{1 0 0 . 0}$ \\
\hline \multicolumn{2}{|c|}{ Master's Degree } & 19 \\
\hline With Units Total & 2 & 76.0 \\
\hline Full Pledged & $(1)$ & 8.0 \\
\hline Master of Educational Management & $(1)$ & \\
\hline Master of Business Administration & 4 & 16.0 \\
\hline No Answer & $\mathbf{2 5}$ & $\mathbf{1 0 0 . 0}$ \\
\hline \multicolumn{2}{|c|}{}
\end{tabular}

The Table 2 implies that half, 13 individual or $52 \%$, of the teacher-respondents have a baccalaureate degree in BEED-BSED , 7 or $28 \%$ are Bachelor of Music holders, 1 or $4 \%$ is a Bachelor of PE holder, 1 or $4 \%$ is a BSBA holder and another 1 or $4 \%$ is ABSE-PHEM holders. The result implies that bulk of the teacher-respondents are BEED-BSED holders. Moreover, the course BEED-BSED is an in-demand courses everywhere, even in a very remote municipality, some of the schools offered BEED-BSED course to cater their students dreams to become a teacher. If a student wanted to specialized music they need 
ample budgets to go in the city where big colleges and universities reside and offered countless courses to choose from.

Finally, 2 or $8 \%$ were full pledged in Master's Degree: 1 or $4 \%$ had Master of Educational Management and another 1 or $4 \%$ Master of Business Administration, and 19 or $76 \%$ teacher-respondents earned few units in master's degree. The teacher who specialized the Educational Management will fave a way to be promoted as Head Teacher. Out of 25 teacher-respondents, nobody pursues a Doctoral Degree, this implies that teachers who teaches Music can still teach the Music subject even if they do not have a Doctoral Degree. Furthermore, based on the interview with the teacher-respondents belong to the age range of 40 49 years old and 50 to 59 years old, they already lack interest in pursuing their teaching career to the next level because they will eventually retire in their teaching career. One of them, from the full pledged in Master Degree, admitted that she could not see the benefits she could get from having a Doctoral Degree because higher salary demands a longer time working at school and lesser time for her family. She believed that she was already at the peak of her career as a teacher.

However, there are 4 or $16 \%$ had no response, as observed during the interview most of the teacherrespondents belong to the age range of 23 to 29 , too early to have a Doctoral Degree. As well as they were very young and newly hired teachers.

Table 3 shows the frequency and percentage distribution of the field of specialization of the teacherrespondents. Teachers instructional performance plays an important rule in terms of the student learning and academic success. Teachers who are satisfied with their work can elevate their best self to do their work appropriately.

Table 3

Field of Specialization of the Teacher-Respondents

\begin{tabular}{|c|c|c|}
\hline Specialization & Frequency & Percentage \\
\hline \multicolumn{3}{|l|}{ Undergraduate } \\
\hline Music Education & 6 & 24.0 \\
\hline MAPEH & 4 & 16.0 \\
\hline English & 3 & 12.0 \\
\hline
\end{tabular}




\begin{tabular}{|l|c|c|}
\hline PE & 2 & 8.0 \\
\hline P E H M & 2 & 8.0 \\
\hline Religious Education & 2 & 8.0 \\
\hline Banking and Finance & 1 & 4.0 \\
\hline Economics & 1 & 4.0 \\
\hline Home Economics & 1 & 4.0 \\
\hline Music & 1 & 4.0 \\
\hline Physical Sciences & 1 & 4.0 \\
\hline Piano & 1 & 4.0 \\
\hline & 25 & 100.0 \\
\hline
\end{tabular}

The data in Table 3 shows the specialization of the teacher in teaching music subject. Out of 25 teacher-respondents 6 individuals or 24\% have a degree in Music Education, MAPEH (4 individuals, 16\%), English (3 individuals, 12\%), PE (2 individuals, 8\%), PEHM (2 individuals, $8 \%$ ), Religious Education (2 individuals, $8 \%$ ), Banking and Finance (1 individuals, 4\%), Economics ( 1 individuals, $4 \%$ ), Home Economics (1 individuals, 4\%), MUSIC (1 individuals, 4\%), Physical Sciences (1 individuals, 4\%), and finally Piano (1 individuals, $4 \%)$.

These results imply that majority of the teacher-respondents do not have a proper training in teaching Music subject, and also their preferred baccalaureate and master's degrees are not specialized in teaching Music subject. This indicates that the teacher-respondents have limited knowledge and skills in teaching music subject effectively.

The table 4 shows the grade level taught by teachers. Every year, teachers are randomly assigned to teach different grade level: Grade 7, 8, 9, and 10. This is to enhance their skills in teaching different levels with different learning styles. Based on the interview, some of the teachers handle different grade level and taught different subjects each year. Yet, it could endanger the standard of learning to the students because some of their teachers did not specialized the subject that they handled. 
Table 4

Grade Level Taught by Teachers

\begin{tabular}{|l|c|c|}
\hline Grade Level & Frequency & Percentage \\
\hline \multicolumn{2}{|l|}{ School Year 2018-2019 } \\
\hline Grade 7 & 15 & 60.0 \\
\hline Grade 8 & 12 & 48.0 \\
\hline Grade 9 & 16 & 64.0 \\
\hline Grade 10 & 5 & 20.0 \\
\hline
\end{tabular}

School Year 2016-2017

\begin{tabular}{|l|c|c|}
\hline Grade 7 & 13 & 52.0 \\
\hline Grade 8 & 13 & 52.0 \\
\hline Grade 9 & 9 & 36.0 \\
\hline Grade 10 & 3 & 12.0 \\
\hline
\end{tabular}

School Year 2014-2015

\begin{tabular}{|l|c|c|}
\hline Grade 7 & 14 & 56.0 \\
\hline Grade 9 & 1 & 4.0 \\
\hline Grade 10 & 2 & 8.0 \\
\hline
\end{tabular}

Table 4 shows that most teacher-respondents experienced a shuffling method in teaching- in which teachers will teach different grade level every year. The researcher also examined the teacher-respondents previous three years of teaching experienced, to test their flexibility in handling students belong to different grade level. During the school year of 2014 to 2015, half of the teacher-respondents, 14 or $56 \%$ taught Grade 7, 2 or $8 \%$ taught Grade 10 and 1 or $4 \%$ taught Grade 9 . The result shows that teacher-respondents did not handle Grade 8, because some of the teacher-respondents were newly hired or recently transferred from the said schools and they were not assigned to Grade 8. In the School Year 2016 to 2017, 13 or 52\% taught Grade 7, another 13 or $52 \%$ taught Grade 8, 9 or $36 \%$ taught Grade 9 and 3 or $12 \%$ taught Grade 10. School Year 2018 to 2019 , more than half, 16 or $64 \%$ of teacher-respondents taught Grade 9,15 or $60 \%$ taught Grade 7, 12 or $48 \%$ of teacher-respondents taught Grade 8 and finally, 5 or $12 \%$ taught Grade 10.

Table 5 shows the frequency and percentage distribution of the teacher-respondents involvement in professional development activities within the past three years of teaching experience.

Table 5

Teaching Experience of Teacher-Respondents

\begin{tabular}{|l|c|c|c|}
\hline Experience & Frequency & Percentage & Interpretation \\
\hline Years in Service & & \\
\hline Less than 5 years & 10 & 40.0 & Junior \\
\hline
\end{tabular}




\begin{tabular}{|l|c|c|l|}
\hline $5-10$ & 2 & 8.0 & Senior \\
\hline $11-15$ & 2 & 8.0 & Master teacher 1 \\
\hline $16-20$ & 2 & 8.0 & Master Teacher 2 \\
\hline 21 years and above & 3 & 12.0 & Master Teacher 3 \\
\hline No answer & 6 & 24.0 & ----- \\
\hline \multicolumn{1}{|c|}{ Total } & $\mathbf{2 5}$ & $\mathbf{1 0 0 . 0}$ & \\
\hline
\end{tabular}

The Table 5 shows that 10 or $40 \%$ teacher-respondents had an experience in teaching for less than 5 years (Junior). 2 or $8 \%$ belong to a Senior Category, with a 5 to 10 years of teaching experience. 2 or $8 \%$ teacher-respondents belongs to a Master Teacher 1 category, with 11 to 15 years of experience in teaching, 2 or $8 \%$ teacher-respondents belongs to a Master Teacher 2 category, with 16 to 20 years of experience in teaching, 3 or $12 \%$ teacher-respondents belongs to a Master Teacher 3 category, with 21 years or more experiences in teaching. And there are 6 or $24 \%$ teacher-respondents with no response, as they were newly hired teachers.

The results imply that most of the teacher-respondents experienced less than five years in teaching profession. Based on the observation during the interview they are very young and are newly hired teachers, some of them were fresh graduate that are very competitive and highly committed in their teaching profession. As a result, they prefer to stay in the profession as a teacher despite of the difficult demands of the teaching job because of their desire to get a promotion to a higher position as well as to earn a bigger salary. While few of them spent half of their lives teaching and got promoted due to a longer length of service.

Table 6 shows the frequency and percentage of the teacher-respondents in accordance to their skills in teaching music. The teacher's skills in teaching music subject are very crucial to have a positive impact to the child's learning. Table 6 shows the frequency and percentage of the teacher-respondents in accordance to their skills in teaching music. The teacher's skills in teaching music subject are very crucial to have a positive impact to the child's learning. According to Helen F. Ladd (2013), experienced teachers are on average more effective in raising student achievement than their less experienced counterparts. 
Teaching strategies should be enjoyable, challenging and also achievable by the students who participated in the music subject. Teachers should be supportive and should find ways to become creative like conducting a group activity to build social skills. In academic world music is very valuable subject because it can enhance the students well being and for those who wanted to pursue their singing career and for those who pursue it for enjoyment.

Table 6

Skills of Teacher-Respondents in Teaching Music

\begin{tabular}{|c|c|c|c|c|}
\hline Skills & & Frequency & & Percentage \\
\hline Singing & 22 & & 88.0 & \\
\hline Reading Notes & 18 & & 72.0 & \\
\hline Dancing & & 2 & & 8.0 \\
\hline Playing Musical Instruments & 20 & & 80.0 & \\
\hline Guitar & 17 & & 68.0 & \\
\hline Organ & 17 & & 68.0 & \\
\hline Piano & 16 & & 64.0 & \\
\hline Violin & 6 & & 24.0 & \\
\hline Drum set & & 6 & & 24.0 \\
\hline Flute & & 4 & & 16.0 \\
\hline Clarinet & & 3 & & 12.0 \\
\hline Saxophone & & 2 & & 8.0 \\
\hline Indigenous & & 2 & & 8.0 \\
\hline Guitar & 1 & & 4.0 & \\
\hline
\end{tabular}

The Table 6 shows the Skills of Teachers, out of 25 teacher-respondents 22 or $88 \%$ had skills in singing, 18 or $72 \%$ teacher-respondents had skills in Reading Notes, 2 or $8 \%$ teacher-respondents had skills in Dancing, 20 or $80 \%$ of the teacher-respondents said that they can play musical instrument, 17 or $68 \%$ teacher-respondents can play guitar and another 17 or $68 \%$ teacher-respondents can play organ. From the 25 teacher-respondents, 16 or $64 \%$ can play piano, 6 or $24 \%$ can play violin and another 6 or $24 \%$ can play drum set. Out of 25 teacher respondents, 4 or $16 \%$ can play flute, 3 or $12 \%$ can play clarinet, 2 or $8 \%$ can play saxophone and another 2 or $8 \%$ can play indigenous. Only, 1 teacher-respondent can play the guitar skillfully.

The results imply that the teacher-respondents somehow have skills, this is a positive indication that even if they belonged to different baccalaureate courses still, they have room for improvement. Through proper trainings, seminars and a well-developed lesson plan will help enhance the teacher's knowledge and will create a positive learning outcome to their students. Experienced teachers also strengthen 
education in other ways beyond improving test scores, they will also help create and maintain a strong school community (Ladd H.F., 2013).

\section{What is the performance of music students in terms of content-standards, as made evident in music theory?}

Table 7 shows the frequency and percentage of the performance of the students in content standards as made evident in Music Theory. Content standard helps motivate the student to achieve at high levels in terms of their academic performance, as it defines the valued knowledge that students are expected to learn from their lessons.

Table 7

Performance of the Students in Content Standards as made evident in Music Theory

\begin{tabular}{lll}
\hline $\begin{array}{l}\text { Question } \\
\text { Item \# }\end{array}$ & Frequency & Percent Music Theory \\
\hline
\end{tabular}

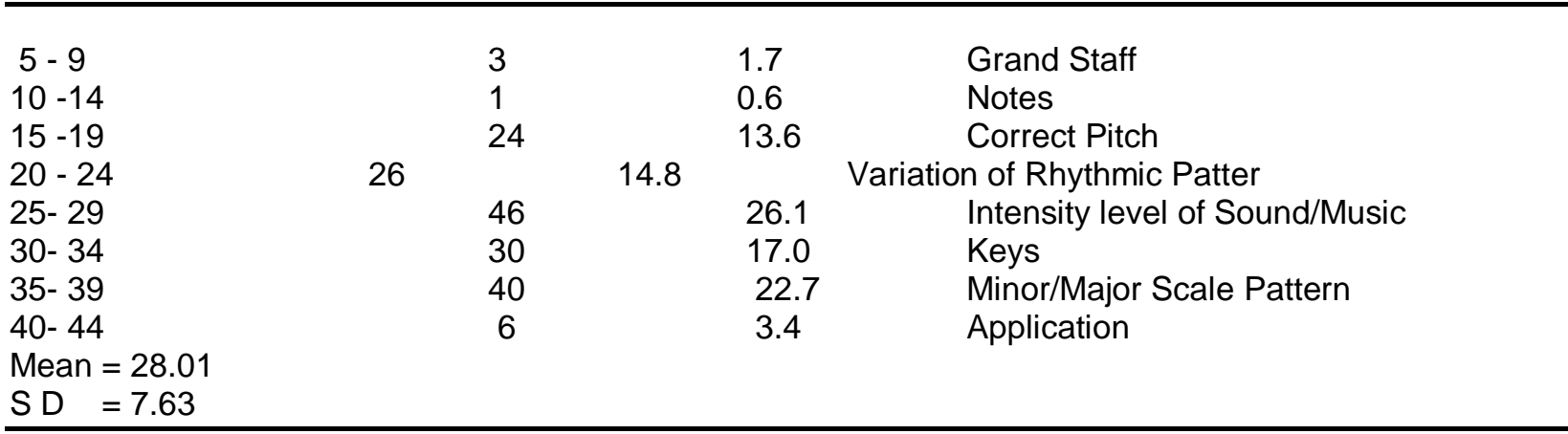

The Table 9 shows the Performance of the Students in Music Theory. The highest possible score for the Music Theory is 44 points. It shows that majority, 46 or 26 percent of students who got a correct answer to question item \# 25 to 29 : Intensity level of Sound/Music, 40 or 22.7 percent of students who got a correct answer to question item \# 35 to 39: Minor/Major Scale Pattern, 30 or 17 percent of students who got a correct answer to question item \# 30 to $34 ; 26$ or 14 percent of the students who got a correct answer to the question item number 20 - 24:Variation of Rhythmic Pattern; 24 or 13.6 percent of students who got a correct answer to question item \# 15 to 19: Correct Pitch; 6 or 3.4 percent of students who got a correct answer to question item \# 40 to 44: Application; 3 or 1.7 percent of students who got a correct answer to question item \# 5 to 9: Grand Staff, and only one student-respondent, 1 or 0.6 percent who got a correct answer to the question item number 10 to 14: Notes. 
Music theory is very crucial component in learning the fundamentals in music education and it helps the students to excel in playing musical instrument. Furthermore, learning the music theory helps the students to stay on the right path in understanding the steps in creating a good music performance. It is a way to enhance the student's cognitive ability to comprehend the importance of notation, keys, pitch, melody, harmony and scales.

The result of the study implies that the performance of the students in content standards as made evident in music theory varies from their knowledge about the topic. During the survey, an informal interview has been initiated by the researcher, some of the student mentioned that "they just answer the questions which they had already learned and understood during their classroom discussions."

The mean of the performance of the students in content standards as made evident in music theory is 28.01 and its standard deviation is 7.63 .

Table 8 shows the frequency and percentage of the student performance in music. Music subject can help the student organized their other activities outside the school campus. The scheduled practice can motivate the student to have time management and self-discipline

Table 10

Interpretation of the Student Performance in Music Theory

\begin{tabular}{|c|c|c|c|c|}
\hline Score Range & Frequency & & Percentage & Interpretation \\
\hline$\overline{1-10}$ & 10 & & 5.68 & Beginning (B) \\
\hline $11-20$ & 0 & & 0 & Developing (D) \\
\hline $21-30$ & 80 & & 45.45 & Approaching Proficient (AP) \\
\hline $31-40$ & 40 & & 22.73 & Proficient $(\mathrm{P})$ \\
\hline 41 and above & 46 & 26.14 & Advá & ed $(A)$ \\
\hline
\end{tabular}

The table 10 shows 80 student-respondents or 45.45 percent with a score range of $21-3$ ), belonged to "approaching proficient (AP)"; 46 or 26.14 percent with a score range of 41 and above, belonged to "advanced"; 40 or 22.73 percent of the student-respondents belonged to "proficient" with an average score range of 31 to 40 ; there are 10 or 5.68 percent of the student-respondents belonged to "beginning" with an average score range of 1 to 10 ; and none of the respondents belonged to "developing" with a score range of 11 to 20 .

Music theory is an important foundation for any musician for several reasons. It helps deepens the student's ability to understand the structure of music. In learning music, students must understand how a piece of music works and why a certain note was chosen. For the students who wanted to play in an 
ensemble or in a local band music theory will helps them analyzed their skills and show them where their part is in the group-making it easier for them to play with other musicians.

Table 9 shows the music indicators such as instrumental and vocal in the performance of the students. In the instrumental and vocal performance of a student, teachers play an important role in how effectively teachers promote music learning. the teaching experience of a teacher will assist the students positive performance towards music.

Table 11

Performance of the Students

\begin{tabular}{|c|c|c|c|c|}
\hline $\begin{array}{l}\text { Music Indicators } \\
\text { SD }\end{array}$ & & $\mathrm{N}$ & & Mean \\
\hline Instrumental & 63 & & & \\
\hline Melody & 4.35 & & 0.55 & \\
\hline Rhythm & 4.16 & & 0.54 & \\
\hline Timbre & 3.79 & & 0.47 & \\
\hline Dynamic & & 4.03 & & 0.56 \\
\hline Musicianship & & 4.06 & & 0.55 \\
\hline Stage presence & 3.91 & & 0.47 & \\
\hline Over - all & & 24.31 & & 2.69 \\
\hline Vocal & & 114 & & \\
\hline Melody & 4.27 & & 0.65 & \\
\hline Rhythm & 4.10 & & 0.59 & \\
\hline Timbre & 3.97 & & 0.54 & \\
\hline Dynamic & & 4.02 & & 0.57 \\
\hline Musicianship & & 4.15 & & 0.67 \\
\hline Stage presence & 4.06 & & 0.53 & \\
\hline Over - all & & 24.57 & & 3.10 \\
\hline
\end{tabular}

Table 11 shows the music indicators used in determining the level of performance of the student. There are 177 student-respondent participated in this study, 63 or 36 percent in "instrumental" and 114 or 64 percent in "vocal".

Generally, learning occurs everywhere, inside the classroom, at home or even in an informal context such as in the public places; it takes place through interactions between children within his/her environment.

\section{Is there a significant difference in student performance in terms of content-standards and} performance-standards? 
Table 12 shows the difference in student performance in terms of content-standards and performancestandards. The performance assessment is very important to assess the child's standing and of what the students should know and be able to do.

Table 12

T - Test Result on Students' Performance on Music Theory and Actual Performance $(\mathrm{N}=176)$

\begin{tabular}{|l|c|c|c|c|c|c|}
\hline \multicolumn{1}{|c|}{ Variable/Factor } & $\begin{array}{c}\text { Mean } \\
\text { in Percent }\end{array}$ & Mean difference & Standard error & df & t & P-value \\
\hline Music Theory & 60.88 & 18.60 & 1.40 & 175 & 14.815 & .0001 \\
\hline Musical Performance & 81.65 & & & & & \\
\hline
\end{tabular}

$r=.081 \quad{ }^{*} \mathrm{P}<.05$

Ho: There is no Significant difference.

Table 12 shows the application of the paired samples t-test revealed the existence of significant differences between the student's score in Music Theory and their corresponding musical performance. The probability of the $t-$ value is less than .05 . Hence, the null hypothesis is rejected. Therefore, the students' performance on the music theory is significantly different from their musical performance. The mean of the variable music theory is 60.88 percent compared to the musical performance which is 81.65 percent.

Teacher helps the students to improve their music performance, thus, they are like a scaffolding who specialized the instructional support to facilitate the child's needs. During practice, learning materials will support the students to acquire music knowledge and skills for communicating and enacting music.

Table 13 shows the summary of one-way analysis of variance results on the performance in music theory. Indeed, music theory is the backbone for a positive result to the students' performance.

Table 13

Summary of One-Way Analysis of Variance Results on the Performance in Music Theory

\begin{tabular}{|c|c|c|c|c|c|}
\hline Factor/ Source of variation & Sum of Square & df & Mean square & $\mathrm{f}$ & P-value \\
\hline \multicolumn{6}{|c|}{ Educational Qualification of Teachers } \\
\hline Between Groups & 121.033 & 2 & 60.517 & 1.040 & .358 \\
\hline Within Groups & 10061.961 & 173 & 58.162 & & \\
\hline Total & 10182.994 & 175 & & & \\
\hline \multicolumn{6}{|l|}{ Teaching Experience } \\
\hline Between groups & 809.684 & 2 & 404.842 & 7.271 & .001 \\
\hline
\end{tabular}




\begin{tabular}{|c|c|c|c|c|c|}
\hline Within groups & 6681.063 & 120 & 55.676 & & \\
\hline
\end{tabular}

${ }^{*} \mathrm{p}<.05$

Ho: There is no significant difference on the students' performance in music theory in terms of teachers' educational qualification and teaching experience. Results from the analysis of variance showed that teaching experience is an important factor that influences the performance of the students on music theory. Results revealed that students whose teachers have long experience tend to get higher scores in music theory. However, students' performance in music theory did not significantly differ when group by teachers' educational qualification. The F - value 7.271 in teaching experience reached the required value for significance but not the $\mathrm{F}$ - value in educational qualification. Hence, the Ho is rejected for teaching experience but not for teachers' educational qualification.

Table 14 shows the summary of one-way analysis of variance results on the students' musical performance. Performance skills can make the student transfer their knowledge from trainings to other facets of their entity. Through their trainings, student can learn how to be confident in front of the crowd and can handle things even if things may not go as planned, they can still perform. To this extent, the learned skills from school is a pivotal to their confidence to other moments in their educational and social lives.

\section{Table 14}

Summary of One-Way Analysis of Variance Results on the Students' Musical Performance

\begin{tabular}{|c|c|c|c|c|c|}
\hline Factor/ Source of variation & Sum of Square & $\mathrm{df}$ & Mean square & f & P-value \\
\hline \multicolumn{6}{|c|}{ Educational Qualification of Teachers } \\
\hline Between Groups & 38.566 & 2 & 19.283 & 2.238 & .110 \\
\hline Within Groups & 1498.948 & 174 & 8.615 & & \\
\hline Total & 1537.514 & 176 & & & \\
\hline \multicolumn{6}{|l|}{ Teaching Experience } \\
\hline Between groups & 95.402 & 2 & 47.701 & 6.757 & .002 \\
\hline Within groups & 854.139 & 121 & 7.059 & & \\
\hline Total & 949.541 & 123 & & & \\
\hline
\end{tabular}

$$
{ }^{*} \mathrm{p}<.05
$$

Ho: There is no significant difference on the students' performance in music performance in terms of teaching experience. In Educational Qualification of Teachers, the p-value is .110 and for the teaching experience of the teachers the $p$-value is 0.002 , There is not sufficient evidence to reject the null hypothesis, 
$p$-value 0.110 of educational qualification of a teacher is greater than the significance level of $\alpha=0.05$, fail to reject the Ho. Thus, data is not statistically significant to the educational qualification of a teacher.

The table 15 shows the students music score by teachers' educational qualification and teaching experience. Every classroom should have a well-qualified teachers, school administrators should check the teachers qualification before handling them the subjects.

Table 15

Students Music Score by Teachers' Educational Qualification and Teaching Experience

\begin{tabular}{|c|c|c|c|}
\hline Factor & $\mathrm{N}$ & Mean & SD \\
\hline \multicolumn{4}{|c|}{ Education Qualification } \\
\hline Bachelor's Degree & 71 & 27.0563 & 8.303 \\
\hline With Master's Units & 88 & 28.8068 & 7.277 \\
\hline Masters degree & 17 & 27.8235 & 6.267 \\
\hline Total & 178 & 28.0057 & 7.628 \\
\hline \multicolumn{4}{|c|}{ Teaching Experience (in years) } \\
\hline $1-9$ & 84 & 25.7857 & 7.249 \\
\hline $10-19$ & 21 & 30.4286 & 7.580 \\
\hline $20-29$ & 18 & 32.1111 & 8.2952 \\
\hline Over-all & 123 & 27.5041 & 7.8358 \\
\hline
\end{tabular}

Table 15 shows the total responses of 88 with a mean of 28.8068 got a correct score with teachers who have units in Masteral.

The teacher competence such as the mastery of subject matter and interest in continued professional improvement will become effective in applying the principles of teaching, thus the student's achievement will be improved.

The findings of the study show that the continued professional improvement of a teacher (gaining masteral units) will improve their teaching styles and principles of teaching to suit the student's cognitive level.

There are 84 total responses of students, with a mean of 25.7857 and a standard deviation of 7.249, who got a correct score with teachers who have 1-9 years in teaching experience. Many researchers believed that when the teacher gains knowledge about teaching through the continued years in service, their students will also gain a better performance.

Table 16 shows the students musical performance by teachers' educational qualification and teaching experience. Music can help the students to become creative and they will be specialized skills in music. 
Table 16

Students Musical Performance by Teachers' Educational Qualification and Teaching Experience

\begin{tabular}{|c|c|c|c|}
\hline Factor & $\mathrm{N}$ & Mean & SD \\
\hline \multicolumn{4}{|c|}{ Education Qualification } \\
\hline Bachelor's Degree & 71 & 24.0657 & 8.303 \\
\hline With Masteral Units & 89 & 24.5768 & 7.277 \\
\hline Master's degree & 17 & 25.7059 & 6.267 \\
\hline Total & 177 & 24.4802 & 7.628 \\
\hline \multicolumn{4}{|c|}{ Teaching Experience (in years) } \\
\hline $1-9$ & 84 & 23.9881 & 2.855 \\
\hline $10-19$ & 21 & 24.2857 & 2.632 \\
\hline $20-29$ & 19 & 21.6316 & 1.474 \\
\hline Over-all & 124 & 23.6774 & 2.778 \\
\hline
\end{tabular}

Table 16 shows the students musical performance by teachers' educational qualification and teaching experience. Teachers in music consider the teaching as an art. It demands time, humor, understanding and hard work. There is a favorable response from the student's musical performance if their teachers have masteral unit's, and not so far away, students with a bachelor's degree gain a positive response. Teachers with 1 to 9 years of teaching experience gained a positive response from the student's performance. Many researches believed that teaching experience is positively associated with student achievement throughout their teaching career. As a newly hired teacher, they experience hardships in teaching during initial years, but continue to be significant as teachers when they reach the second, and often third, decades of their careers. Most of the teacher will accumulate knowledge when they have the support from their co-teachers and students. As a result, as teacher gain knowledge year after year of service in teaching profession, their students become better and better as they learned from their experienced teacher. Not only inside the four walls of the classroom but also in the society as a whole.

\section{SUMMARY, CONCLUSIONS, AND RECOMMENDATIONS}

1. This study conducted an assessment in the five pioneering SPA schools in Region X, namely, Bukidnon National High School (BNHS), in Malaybalay City; Gingoog Comprehensive National High School, in Gingoog City; Iligan City East High School (ICEHS), in Santa Filomena, Iligan City; Lapasan National High School, in Cagayan de Oro City; and Misamis Occidental National High School (MONHS), in Oroquita City. 
2. Most of the teacher-respondents were females.

3. Most of the teacher-respondents belong to the age range of 23 to 29 years old, they were young and a newly hired professional teachers.

4. Most of the teacher-respondents have a baccalaureate degree in BEED-BSED.

5. Most of the teacher-respondents earned few units in master's degree.

6. Most of the Teacher-respondents had an experience in teaching for less than 5 years (Junior).

7. The participants of the study were all the Grade 9 SPA Music students in the selected SPA schools in Region X, during the school year 2019-2020.

8. There are two (2) sets of assessment tools used in this study to evaluate knowledge on music theory and singing ability of students: first set of tools was a 44-item written examination and the second set was a Scoring Rubrics to rate the singing ability of the students.

9. Most of the student-respondents mastered the Intensity level of sound/music and they also Mastered the minor/major scale pattern. A clear evident that after seventeen years of implementation of SPA Music Program, teachers and administrator enhance their teaching-learning styles to suit the needs of the students.

10. The students' performance in music theory is approaching proficient indicates that the SPA Music Program is well-organized and still progressing.

11. The Music Theory and Actual Performance of the students was measured with the used on a generative theory of Tonal Music of Fred Lerdahl and Ray Jackendoff (1983) (rhythmic, pitch organization, dynamic and timbral differentiation). The students' performance on the music theory is significantly different from their musical performance.

12. Descriptive statistics and inferential analysis such as ANOVA, t-test were used to examine and evaluate the music instruction in the Special Program in the Arts in selected SPA schools in Region X.

\section{Conclusions}

1. After seventeen years of implementation of SPA Music Program, the five pioneering SPA schools in Region X, namely, Bukidnon National High School (BNHS), in Malaybalay City; Gingoog Comprehensive National High School, in Gingoog City; lligan City East High School (ICEHS), in Santa 
Filomena, Iligan City; Lapasan National High School, in Cagayan de Oro City; and Misamis Occidental National High School (MONHS), in Oroquita City are still assessing and finding a better way to cater the student needs in terms of teaching and learning of music.

2. Based on the theory of learning by David Ausubel, students' cognitive structure is related to

3. Previously learned content forming new connections between new information and the existing information. Inside the classroom, teachers have the most contact time with the students and may be the sole provider of music instruction (Gold, 1973; Gray, 2000). Thus, teacher's attitudes, skills and educational qualifications create a great impact and contribute to the student's performance in terms of content-standards and performance-standards. The study concludes that the students' performance on the music theory is significantly different from their musical performance.

4. Through the careful implementation of the revised content-standards and performance-standards may enhance the student's critical thinking and student's performance.

\section{Recommendations}

The following recommendations are made, based on the viable findings of this research.

1. As a fresh hired teacher, they should undergo a more in-depth trainings to assure the accuracy of the content standard and developed skills that are necessary for teaching Music education.

2. The criteria for hiring and appointing teachers must include examination for the music theory or content standard. One must be promoted if they already pass the exam about the content and pedagogical knowledge in teaching music education.

3. It is recommended that there should be a body of committee to draft a national promotional examination for teachers handling music education.

\section{REFERENCES}

Cambridge Dictionary. (2020, February 27). Meaning of postulate in English. Retrieved from Cambridge Dictionary: https://dictionary.cambridge.org/dictionary/english/postulate

Congress of the Philippines. (2001, August 11). Official Gazette. Retrieved from officialgazette.gov.ph. 
Department of Education. ( 2003, January 6). DepEd Memoranda. Retrieved from deped.gov.ph: https://www.deped.gov.ph/wp-content/uploads/2019/10/DM_s2019_138-2.pdf

Department of Education. (2003a, September 29). DepEd Memoranda. Retrieved from www.deped.gov.ph/: https://www.deped.gov.ph/2003/09/29/september-29-2003-dm-383-s-2003-national-conference-of-keyimplementors-of-the-special-program-for-the-arts/

Department of Education. (2003a, January 6). DepEd Memoranda. Retrieved from deped.gov.ph: https://www.deped.gov.ph/wp-content/uploads/2019/10/DM_s2019_138-2.pdf

Department of Education. (2003c, April 29). DepEd Memoranda. Retrieved from deped.gov.ph: https://www.deped.gov.ph/2003/04/29/april-29-2003-dm-139-s-2003-training-of-teachers-for-the-specialprogram-for-the-arts/

Department of Education. (2003d, February 3). DepEd Memoranda. Retrieved from deped.gov.ph: https://www.deped.gov.ph/2003/02/03/february-3-2003-dm-27-s-2003-national-conference-of-keyimplementors-of-the-special-program-for-the-arts-and-sports/

Department of Education. (2012, April 17). DepEd Order. Retrieved from deped.gov.ph: https://www.deped.gov.ph/wp-content/uploads/2012/04/DO_s2012_31.pdf

Department of Education. (2012, April 17). DepEd Order. Retrieved from www.deped.gov.ph/: https://www.deped.gov.ph/wp-content/uploads/2012/04/DO_s2012_31.pdf

Department of Education Region-X Northern Mindanao. (2017, November 17). Memoranda 2017. Retrieved from deped 10.com: https://doc-04-9k-

docs.googleusercontent.com/docs/securesc/41lf41 bgtruqmcv6pddvf1 ulf6h1 kgf5/vhioo5fa08iljev7udkfcgtd durh19in/1582618500000/08020111198867334943/10573928503314390192/1JojjQXfS43z2NZBKwPFcYj1c-NNd20f?e=downloadtarget\%3D\%27_blank\%27\&authuser

Department of Education Region-X Northern Mindanao. (2018, December 7). Memoranda 2018. Retrieved from http://deped10.com/: https://drive.google.com/file/d/1nZONOfgYZzhUtJSyHzhp2pUG4URTL1Gn/view

Guevarra, A.V. (2011). Teaching Performance as Influenced by Educational Qualification. Vol. 15 No. 7. Retrieved from https://lsu.edu.ph/application/files/8714/7184/3058/Vol._15_No._7_-

_Teaching_Performance_as_Influenced_by_Educational_Qualification.pdf

Ladd, H.F. (2013). What can be done to develop the why Experienced teachers are important- and what can be done to develop them. Retrieved from https://scholars.org/contribution/why-experienced-teachersare-important-and-what-can-be-done-develop-them.

Kini, T. \& Podolsky, A. (2016). Teaching Experience and Teacher Effectiveness. Retrieved from HYPERLINK "https://www.aft.org/ae/fall2016/notebook" https://www.aft.org/ae/fall2016/notebook.

Music \& Arts (2017). The Importance of Learning Music Theory.

Retrieved from http://thevault.musicarts.com/importance-of-learning-musictheory/\#: :text=At\%20its\%20core\%2C\%20music\%20theory,these\%20questions\%2C\%20and\%2 0many\%20more. 
Ninio, A., \& Bruner, J. (1978). The Achievement and Antecedents of Labelling. Journal of Child Language, 5, 115.

Palincsar, A. (1986). The Role of Dialogue in Providing Scaffolded Instruction. Educational Psychologist, 21 (1\&2), 73-98.

Phil Barrow (2017). The Importance of Music Theory. Retrieved from https://resoundschool.com/importance-music-

theory/\#: :text=Learning\%20music\%20theory\%20sets\%20students, melody\%2C\%20harmony\%2C\%20an d\%20more.

PIANO PEDAGOGY (2019).Why Music Education Is Important. Retrieved from https://www.houstonpianocompany.com/blog/piano-pedagogy/why-music-education-is-important

Vygotsky, L. (1987). Thinking and Speech. In R. Rieber, \& A. E. Carton, L.S. Vygotsky, Collected Works Vol. 1 (pp. 39-285). New York: Plenum. 